\title{
Somatosensory findings in patients with spinal cord injury and central dysaesthesia pain
}

\author{
Per Kristian Eide, Ellen Jørum, Aud E Stenehjem
}

\begin{abstract}
Objective-To determine whether central pain in patients with spinal cord injury is only dependent on the lesioning of spinothalamic pathways.

Methods-In sixteen patients with spinal cord injury and central dysaesthesia pain, somatosensory abnormalities in painful denervated skin areas were compared with somatosensory findings in normal skin areas as well as in non-painful denervated skin areas.
\end{abstract}

Results-The threshold values for detection of thermal (heat, cold, heat pain, or cold pain) and tactile stimulation were significantly changed in denervated skin areas although there were no significant differences in the threshold values between painful and non-painful denervated skin areas. The reductions of sensations of touch, vibration, joint position, and two point discrimination in painful and non-painful denervated skin areas were not significantly different. Allodynia (pain caused by non-noxious stimulation) and wind up-like pain (pain caused by repeatedly pricking the skin) were significantly more common in painful than nonpainful denervated skin areas.

Conclusions-Because pain and thermal sensory perception are primarily mediated to the brain via spinothalamic pathways, whereas the sensations of touch, vibration and joint position are primarily mediated by dorsal column-medial lemniscal pathways, the results indicate that central pain is not only dependent on the lesioning of either dorsal column-medial lemniscal pathways or spinothalamic pathways. The findings of abnormal evoked pain (allodynia and wind up-like pain) may be consistent with the experimental findings of hyperexcitability in nociceptive spinothalamic tract neurons, that may be involved in the pathogenesis of central pain.

$(\mathcal{F}$ Neurol Neurosurg Psychiatry 1996;60:411-415)

Keywords: central pain; spinal cord injury; somatosensory testing

Severe and disabling chronic pain is a major sequel after spinal cord injury, with an estimated prevalence ranging from 18 to $63 \% .^{1}$ Pain in patients with spinal cord injury includes musculoskeletal pain, radicular pain, visceral pain, central dysaesthesia pain, psychogenic pain, lesional pain, reflex sympathetic dystrophy, and limb pain secondary to compressive mononeuropathies. ${ }^{2}$ Central dysaesthesia pain is characterised by spontaneous continuous and intermittent pain as well as by pain evoked by non-noxious stimulation (allodynia). ${ }^{23}$ It is difficult to treat this type of pain as central pain is not effectively relieved by traditional analgesics or neurosurgical procedures. ${ }^{34}$ Increased knowledge of the pathogenesis of central dysaesthesia pain after spinal cord injury is desired.

An important hypothesis is that the development of central pain is dependent on the lesioning of spinothalamocortical pathways. ${ }^{35}$ The hypothesis is partly based on the finding that sensory perception mediated to the brain via spinothalamocortical pathways is more often affected than sensory perception mediated by dorsal column-medial lemniscal pathways in this group of patients. ${ }^{36}$

In the present study, somatosensory testing of patients with spinal cord injury and central dysaesthesia pain was undertaken to further examine whether central pain is only dependent on the lesioning of spinothalamic pathways.

\section{Materials and methods \\ PATIENTS}

Sixteen patients with spinal cord injury with central dysaesthesia pain attending the spinal unit, Sunnaas Rehabilitation Hospital, that were able to and willing to participate, were included in the study. The nature and purpose of the study were described to the patients, and a written informed consent was obtained from each participant. The study was approved by the ethics committee of Health Region II in Norway.

\section{SOMATOSENSORY TESTING}

Testing was performed by the same investigator, and care was taken to avoid stress during testing. Somatosensory testing was carried out within three different skin areas (table 1): (1) a normal skin area above the lesion level; (2) a non-painful denervated skin area with impaired sensory perception; (3) a painful denervated skin area with impaired sensory perception. In this particular skin area the patients reported continuous dysaesthesia pain.

Threshold temperatures for sensations of warm, cold, heat pain, and cold pain were determined by a Somedic Thermotester 
Table 1 Level of somatosensory testing

\begin{tabular}{rlll}
\hline $\begin{array}{l}\text { Patient } \\
\text { No }\end{array}$ & $\begin{array}{l}\text { Normal } \\
\text { skin } \\
\text { area }\end{array}$ & $\begin{array}{l}\text { Non-painful } \\
\text { denervated } \\
\text { skin area }\end{array}$ & $\begin{array}{l}\text { Painful } \\
\text { denervated } \\
\text { skin area }\end{array}$ \\
\hline 1 & T6/T7 & L2/L3 & T12 \\
2 & T8 & C7/S2 \\
3 & C4/C5 & C6 & C8 \\
4 & C4/C5 & L2 & C7 \\
5 & C7 & T7/T8 & S2 \\
6 & C7 & T12/L1 & C8 8 \\
7 & C4 & T7 & C6 \\
8 & C4/C5 & T6 & T6 \\
9 & C4 & L1 & S3-5 \\
10 & C4 & L1 & T10 \\
11 & C6 & C6 & C4 \\
12 & C6 & L5 & C8 \\
13 & C4 & T12/L1 & T12/L1 \\
14 & C4/C5 & & \\
15 & C6 & & \\
16 & &
\end{tabular}

(Somedic AB, Stockholm, Sweden), using a modification of the Marstock method. Testing was performed as previously described. ${ }^{8}$

Threshold values for tactile sensation were assessed by von Frey filaments, applied in an ascending and descending order of magnitude. The force required to bend the filaments was converted to log units.

Two point discrimination was tested with Weber's compasses to determine whether it was reduced in painful and non-painful denervated skin areas compared with normal skin areas.

The sensation of vibration was tested over a bony part with a tuning fork. The aim of the investigation was to evaluate whether this was reduced in painful and non-painful denervated skin areas compared with normal skin areas.

Table 2 Demographic and clinical data

\begin{tabular}{clllllll}
\hline $\begin{array}{c}\text { Patient } \\
\text { No }\end{array}$ & Sex & Age & $\begin{array}{l}\text { Cause of } \\
\text { injury }\end{array}$ & $\begin{array}{l}\text { Level of } \\
\text { injury }\end{array}$ & $\begin{array}{l}\text { ASLA } \\
\text { class }\end{array}$ & $\begin{array}{l}\text { Start of pain } \\
\text { after injury }\end{array}$ & $\begin{array}{l}\text { Duration } \\
\text { of pain }\end{array}$ \\
\hline 1 & M & 72 & $\begin{array}{l}\text { Work, } \\
\text { crushed }\end{array}$ & T12 & A & 3 months & 28 months \\
2 & M & 36 & $\begin{array}{l}\text { Sport, } \\
\text { skiing }\end{array}$ & L1 & C & Immediately & 14 months \\
3 & M & 62 & Fall down & C7 & D & Immediately & 30 months \\
4 & M & 29 & $\begin{array}{l}\text { Sport, } \\
\text { skiing }\end{array}$ & C6 & C & Immediately & 17 months \\
5 & F & 53 & $\begin{array}{l}\text { Road, } \\
\text { passenger }\end{array}$ & L1 & C & 2 months & 26 months \\
6 & M & 45 & $\begin{array}{l}\text { Work, } \\
\text { fall down }\end{array}$ & T8 & A & Immediately & 36 months \\
7 & M & 60 & $\begin{array}{l}\text { Road, } \\
\text { bicyclist }\end{array}$ & C5 & C & Immediately & 24 months \\
8 & M & 25 & $\begin{array}{l}\text { Sport, } \\
\text { diving }\end{array}$ & C6 & A & Immediately & 35 months \\
9 & M & 38 & $\begin{array}{l}\text { Road, } \\
\text { MC driver }\end{array}$ & T6 & A & Immediately & 21 months \\
10 & M & 23 & $\begin{array}{l}\text { Sport, } \\
\text { diving }\end{array}$ & C6 & B & 6 months & 6 months \\
11 & M & 31 & $\begin{array}{l}\text { Road, car } \\
\text { driver }\end{array}$ & T9 & C & Immediately & 68 months \\
12 & M & 52 & $\begin{array}{l}\text { Work, } \\
\text { fall down }\end{array}$ & T10 & A & Immediately & 22 months \\
13 & M & 41 & $\begin{array}{l}\text { Road, car } \\
\text { driver }\end{array}$ & C4 & A & 6 months & 20 months \\
14 & M & 48 & $\begin{array}{l}\text { Road, car } \\
\text { driver }\end{array}$ & C5 & D & Immediately & 36 months \\
15 & F & 25 & $\begin{array}{l}\text { Sport, } \\
\text { fall down }\end{array}$ & C8 & B & Immediately & 36 months \\
16 & M & 35 & $\begin{array}{l}\text { Road, car } \\
\text { driver }\end{array}$ & T12 & A & 2 months & 94 months \\
\hline
\end{tabular}

The American Spinal Injury Association (ASIA) Impairment Scale: A = complete. No sensory or motor function preserved in the sacral segments S4-S5; $B=$ incomplete. Sensory but $n$ motor function preserved below the neurological level extending through the sacral segments S4-S5; C = incomplete. Motor function preserved below the neurological level with muscle grade less than 3 in the majority of key muscles; $D=$ incomplete. Motor function preserved below the neurological level with muscle grade greater than or equal to 3 in the majority of key muscles (see Ditunno et $a l^{2}$ )
The sensation of light touch was examined by gently moving cotton wool over the skin to ascertain whether the sensation to light touch was reduced in painful and non-painful denervated skin areas compared with normal skin areas.

The sensation of joint position was tested conventionally to determine whether it was reduced in painful and non-painful denervated skin areas compared with normal skin areas.

Pain evoked by lateral skin stretch was examined by pulling the skin. The patients responded by reporting whether the skin stretch was painful or non-painful.

Allodynia was assessed by applying an electric toothbrush (Braun D 3, FRG) on the affected skin area until the patient had discomfort, or up to 30 seconds. Allodynia was also evoked by holding a hair dryer over the affected skin area in one patient (No 4) and by pulling the affected skin in another (No 9). Allodynia was recorded as a change in pain intensity, measured by a $100 \mathrm{~mm}$ visual analogue scale $(0=$ no pain, $100=$ unbearable pain), before stimulation and at the peak of pain.

Wind up-like pain was evoked by repeatedly pricking at a rate of $3 / \mathrm{s}$ the affected skin area with a von Frey filament ( 6.65 units) for 30 seconds. If wind up-like pain was present, the stimulation was initially not painful, but after a few seconds the patients reported an increase of pain, which was burning and stinging in quality. This wind up-like pain was recorded as change in pain intensity, measured by a visual analogue scale $100 \mathrm{~mm}(0=$ no pain, $100=$ unbearable pain), before stimulation and at the peak of pain.

\section{STATISTICS}

The data were evaluated by non-parametric statistical analysis. The Wilcoxon signed rank test was used to calculate significant differences between two treatments. Calculations were performed by the computer program Statgraphics version 3.0. Differences in the frequency of abnormal sensory perception between two groups were calculated by $\chi^{2}$ test using Yates' correction when the frequency of any cell was less than 10 . Significance was accepted at the $5 \%$ level.

\section{Results}

PATIENTS

Table 2 shows the demographic and clinical data. The median age was 39.5 years with a median duration of pain of 27 months. The completeness of cord damage was indicated by the ASIA impairment scale (table 2). Spinal cord damage may also involve damage to spinal roots, but no patients had only root lesions. All the patients had continuous dysaesthesia pain with spontaneous intermittent pain and pain could be evoked in $88 \%$ of the patients (table 3 ). The median score of pain intensity on the visual analogue scale was $54 \mathrm{~mm}$, and the median frequency of attacks of intermittent pain was one to two each day. 
Table 3 Pain characteristics

\begin{tabular}{|c|c|c|c|c|c|}
\hline \multirow{3}{*}{$\begin{array}{l}\text { Patient } \\
\text { No }\end{array}$} & \multicolumn{2}{|c|}{ Spontaneous continuous pain } & \multirow{2}{*}{\multicolumn{2}{|c|}{ Spontaneous intermittent pain }} & \multirow{3}{*}{$\begin{array}{l}\text { Evoked } \\
\text { pain } \\
\text { Provoking } \\
\text { factors }\end{array}$} \\
\hline & \multirow[b]{2}{*}{ Description } & \multirow{2}{*}{$\begin{array}{l}\text { Intensity } \\
\text { of pain }\end{array}$} & & & \\
\hline & & & Description & Frequency & \\
\hline 1 & $\begin{array}{l}\text { Aching, cutting } \\
\text { Cruel }\end{array}$ & $59 \mathrm{~mm}$ & $\begin{array}{l}\text { Stinging, } \\
\text { radiating }\end{array}$ & $7-8$ day & Touch \\
\hline 2 & $\begin{array}{l}\text { Pricking/tingling, } \\
\text { burning, aching }\end{array}$ & $49 \mathrm{~mm}$ & $\begin{array}{l}\text { Shooting, } \\
\text { radiating }\end{array}$ & $0-1 /$ week & Touch \\
\hline 3 & $\begin{array}{l}\text { Burning, tightening, } \\
\text { piercing, numbness }\end{array}$ & $55 \mathrm{~mm}$ & Sharp, stinging & $1 /$ week & Touch \\
\hline 4 & $\begin{array}{l}\text { Tightening, } \\
\text { pricking, numbness }\end{array}$ & $25 \mathrm{~mm}$ & Stinging & $>10 /$ day & Touch \\
\hline 5 & Cutting, tingling & $53 \mathrm{~mm}$ & Shooting, sharp & 7/day & Touch \\
\hline 6 & $\begin{array}{l}\text { Tingling, } \\
\text { tightening, } \\
\text { squeezing, piercing }\end{array}$ & $72 \mathrm{~mm}$ & Radiating & $>20 /$ day & Touch \\
\hline 7 & $\begin{array}{l}\text { Aching, burning, } \\
\text { cutting, tingling } \\
\text { pricking, cruel, } \\
\text { piercing }\end{array}$ & $76 \mathrm{~mm}$ & $\begin{array}{l}\text { Shooting, } \\
\text { stinging, } \\
\text { throbbing }\end{array}$ & $>20 /$ day & $\begin{array}{l}\text { Touch } \\
\text { movement }\end{array}$ \\
\hline 8 & Burning, aching & $81 \mathrm{~mm}$ & $\begin{array}{l}\text { Shooting, } \\
\text { stabbing, } \\
\text { stinging }\end{array}$ & $>20 /$ day & Touch \\
\hline 9 & $\begin{array}{l}\text { Piercing, cutting, } \\
\text { tingling }\end{array}$ & $14 \mathrm{~mm}$ & Sharp, radiating & 2/week & Touch \\
\hline 10 & $\begin{array}{l}\text { Tightening, } \\
\text { squeezing }\end{array}$ & $58 \mathrm{~mm}$ & Throbbing & 1-2/day & $\begin{array}{l}\text { Touch } \\
\text { movement }\end{array}$ \\
\hline 11 & Squeezing & $30 \mathrm{~mm}$ & Stinging & $4 /$ week & $\begin{array}{l}\text { Touch, } \\
\text { movement, } \\
\text { cold }\end{array}$ \\
\hline 12 & $\begin{array}{l}\text { Burning, tingling, } \\
\text { tightening, } \\
\text { squeezing }\end{array}$ & $46 \mathrm{~mm}$ & $\begin{array}{l}\text { Stinging, } \\
\text { radiating }\end{array}$ & 4-5/day & $\begin{array}{l}\text { Touch } \\
\text { movement, } \\
\text { cold }\end{array}$ \\
\hline 13 & $\begin{array}{l}\text { Burning, tingling } \\
\text { pricking, aching, } \\
\text { tightening, } \\
\text { squeezing, piercing }\end{array}$ & $73 \mathrm{~mm}$ & $\begin{array}{l}\text { Shooting, sharp, } \\
\text { stinging, } \\
\text { radiating }\end{array}$ & 1-2/day & $\begin{array}{l}\text { Touch } \\
\text { movement, } \\
\text { heat }\end{array}$ \\
\hline 14 & Burning & $32 \mathrm{~mm}$ & - & - & - \\
\hline 15 & $\begin{array}{l}\text { Burning, cutting, } \\
\text { tingling, pricking, } \\
\text { itching, piercing }\end{array}$ & $50 \mathrm{~mm}$ & $\begin{array}{l}\text { Stabbing, sharp, } \\
\text { stinging }\end{array}$ & 4/week & Touch \\
\hline 16 & $\begin{array}{l}\text { Burning, pricking } \\
\text { aching, cruel }\end{array}$ & $87 \mathrm{~mm}$ & - & - & Touch \\
\hline
\end{tabular}

Intensity of continuous pain presented as $\mathrm{mm}$ change on a $100 \mathrm{~mm}$ VAS (no pain-unbearable pain). The word most exactly describing the continuous pain is in italics.

Table 4 Threshold medians (and range) in normal skin area and in non-painful and painful denervated skin areas

\begin{tabular}{|c|c|c|c|}
\hline $\begin{array}{l}\text { Somatosensory } \\
\text { thresholds }\end{array}$ & Normal skin area & $\begin{array}{l}\text { Non-painful } \\
\text { denervated skin } \\
\text { area }\end{array}$ & $\begin{array}{l}\text { Painful } \\
\text { denervated skin } \\
\text { area }\end{array}$ \\
\hline $\begin{array}{l}\text { Warm threshold }\left({ }^{\circ} \mathrm{C}\right) \\
\text { Cold threshold }\left({ }^{\circ} \mathrm{C}\right)\end{array}$ & $\begin{array}{l}35 \cdot 7(33 \cdot 0-42 \cdot 6) \\
31 \cdot 2(26 \cdot 4-32 \cdot 7)\end{array}$ & $\begin{array}{l}39 \cdot 8(34 \cdot 1-52 \cdot 0)^{\star} \\
27 \cdot 9(5 \cdot 0-31 \cdot 2)^{\star \star}\end{array}$ & $\begin{array}{l}49 \cdot 2(34 \cdot 4-52 \cdot 0)^{\star \star \star} \\
16 \cdot 4(5 \cdot 0-31 \cdot 2)^{\star \star \star}\end{array}$ \\
\hline $\begin{array}{l}\text { Heat pain } \\
\text { threshold }\left({ }^{\circ} \mathrm{C}\right)\end{array}$ & $42 \cdot 1(36 \cdot 2-51 \cdot 6)$ & $47 \cdot 2(38 \cdot 6-52 \cdot 0)^{\star}$ & $50 \cdot 5(39 \cdot 4-52 \cdot 0)^{\star \star}$ \\
\hline $\begin{array}{l}\text { Cold pain } \\
\text { threshold }\left({ }^{\circ} \mathrm{C}\right) \\
\text { Tactile threshold }\end{array}$ & $22 \cdot 3(5 \cdot 0-28 \cdot 7)$ & $16 \cdot 4(5 \cdot 0-29 \cdot 1)$ & $5 \cdot 0(5 \cdot 0-27 \cdot 6)^{\star}$ \\
\hline$\left(\log _{10} 0.1 \mathrm{mg}\right)$ & $3.22(1.65-4.44)$ & $4.93(3.84-6.45)^{\star \star \star}$ & $4.19(1.65-6.65)$ \\
\hline
\end{tabular}

$\star \mathrm{P}<0.05 ;{ }^{\star \star} \mathrm{P}<0.01 ;{ }^{\star \star \star} \mathrm{P}<0.005$; Significant differences compared with measurements in normal skin area (Wilcoxon signed rank test).

\section{SOMATOSENSORY FINDINGS}

Table 4 shows the thresholds for temperature and tactile sensation. The thresholds for temperature sensation were more reduced in painful than non-painful denervated skin areas but the difference was not significant $(\mathrm{P}>0 \cdot 10)$.

Table 5 Percentage of patients with abnormal sensory perception

\begin{tabular}{|c|c|c|c|}
\hline & Normal skin area & $\begin{array}{l}\text { Non-painful } \\
\text { denervated skin } \\
\text { area }\end{array}$ & $\begin{array}{l}\text { Painful } \\
\text { denervated skin } \\
\text { area }\end{array}$ \\
\hline $\begin{array}{l}\text { Light touch } \\
\text { Vibration } \\
\text { Joint position } \\
\text { Two point discrimination } \\
\text { Hyperalgesia to lateral skin }\end{array}$ & $\begin{array}{l}0(16) \\
0(15) \\
0(11) \\
0(16)\end{array}$ & $\begin{array}{l}75(16) \\
58(12) \\
40(5) \\
73(11)\end{array}$ & $\begin{array}{l}56(16) \\
62(13) \\
20(10) \\
87(15)\end{array}$ \\
\hline stretch & $0(16)$ & $0(14)$ & $63(16)$ \\
\hline
\end{tabular}

Number of patients tested given in parenthesis. No significant differences in sensory perception between painful or non-painful denervated skin areas were found.

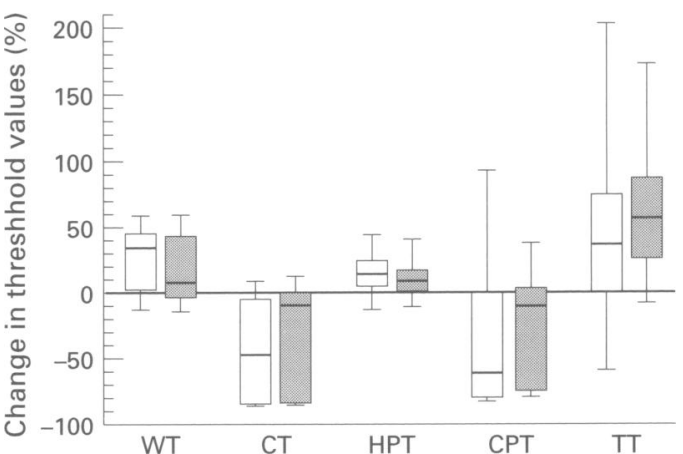

Differences in warm thresholds (WT), cold thresholds (CT), heat pain thresholds (HPT), cold pain thresholds (CPT), and tactile thresholds (TT) between normal skin areas and non-painful denervated skin areas (open boxes) and painful denervated skin areas (cross hatched boxes). Data are presented as box plots with medians represented by the horizontal lines with the 75th percentiles at the top and the 25th percentiles at the bottom of the boxes. Ranges represented as whiskers. There were no statistical differences $(P>0 \cdot 1)$ between the groups (Wilcoxon signed rank test).

A consistent finding was that several of the patients reported a stinging, pin prick-like sensation in denervated skin areas that was more prominent than the thermal sensation. During application of warm or heat pain stimulation, this sensation was demonstrated three times more often in painful than non-painful denervated skin areas.

The tactile sensibility was more reduced in non-painful than in painful denervated skin areas, but the difference was not significant ( $P$ $=0 \cdot 10)$.

The figure shows the percentage difference in thermal and tactile thresholds between normal skin areas and painful or non-painful denervated skin areas.

Table 5 shows the proportion of patients with impaired sensation of light touch, vibration, joint position, or two point discrimination. When comparing sensations in painful and non-painful denervated skin areas, there were no significant differences for the sensations of light touch $(P>0.75)$, vibration $(P>$ $0.5)$, joint position ( $P>0.25)$, or two point discrimination $(\mathrm{P}>0.75)\left(\chi^{2}\right.$ test with Yates correction).

Hyperalgesia to lateral skin stretch was found in 10 of 16 patients in painful denervated skin areas, but was not found in normal skin areas or in non-painful denervated skin areas (table 5).

Table 6 shows the changes in pain intensity during testing of evoked pain (allodynia and wind up-like pain). It was not possible to examine allodynia or wind-up like pain in the painful skin area in patient No 10 because testing provoked painful spasms. In patient No 8 the testing of wind up-like pain caused a local inflammation (about $1 \mathrm{~cm}$ in diameter) in all skin areas tested, and the inflammation was associated with pain different from wind up-like pain. Allodynia and wind up like-pain could not be provoked in normal skin areas. In non-painful denervated skin areas, allodynia was evoked in only one patient and wind uplike pain in three of 16 patients. In denervated 
Table 6 Evoked pain

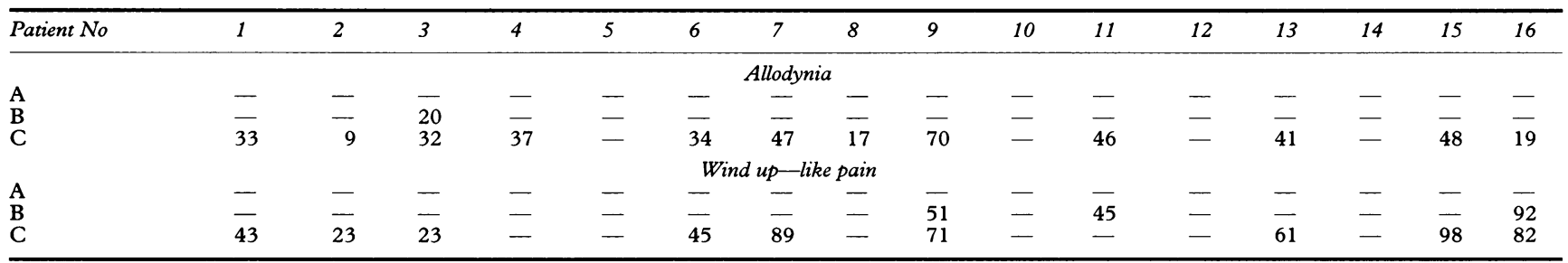

$\mathrm{A}=$ normal skin area; $\mathrm{B}=$ non-painful denervated skin area; $\mathrm{C}=$ painful denervated skin area. Data given as \% change in pain intensity, measured by the VAS, before stimulation and at the peak of pain.

skin areas with pain, allodynia could be evoked in 12 of 15 patients $(80 \%)$. The median intensity of allodynia recorded by means of a 100 $\mathrm{mm}$ visual analogue scale in 12 patients was $36 \mathrm{~mm}$. Furthermore, the median duration of after-sensation pain was 10 seconds (ranges five seconds -15 minutes), and the median diameter of radiation of pain was 10 (range 1-20) $\mathrm{cm}$.

In the painful denervated skin areas, wind up-like pain provoked by a von Frey filament (6.65 units) was evoked in nine of the 14 patients tested. The median intensity of pain recorded by means of a $100 \mathrm{~mm}$ visual analogue scale in the nine patients was $61 \mathrm{~mm}$ with a median duration of after-sensation pain of 15 (range 5-30) seconds and a median diameter of radiation of pain of 8 (range 3-20) $\mathrm{cm}$. The median latency for evoking wind uplike pain was 12 seconds. The difference in the occurrence of wind up-like pain in painful and non-painful denervated skin areas was significant $\left(P<0.05 ; \chi^{2}\right.$ test with Yates' correction). In two of the nine patients wind up-like pain could also be evoked in the painful denervated skin area using a thin von Frey filament $(1.65$ units).

\section{Discussion}

The present results show that sensory perception mediated by spinothalamic or dorsal column-medial lemniscal pathways was not affected more in painful than non-painful denervated skin areas in patients with spinal cord injury and central pain. On the other hand, abnormal evoked pain including allodynia and wind up-like pain was significantly more common in painful than non-painful denervated skin areas.

An important hypothesis is that the development of central pain is dependent on the lesioning of spinothalamocortical pathways. ${ }^{3}$ These pathways seem to be consistently affected in patients with central pain, when comparing the occurrence of central pain with the anatomical location of the lesion. ${ }^{5}$ In patients with central pain of different causes somatosensory perception mediated by spinothalamic pathways is more often affected than somatosensory perception mediated by dorsal column-medial lemniscal pathways. ${ }^{36}$ However, the results are primarily based on somatosensory testing in painful denervated skin areas. To our knowledge, comparison of somatosensory findings in painful and nonpainful denervated skin areas has not been performed. In the present study it was possible to identify a denervated skin area that was non-painful in 14 of 16 patients with spinal cord injury.

We applied various types of cutaneous somatosensory stimuli. Touch, pressure, lateral skin stretch and the sensations of vibration and joint position all activate $A \beta$ low threshold mechanoreceptors whereas thermal stimulation activates $\mathrm{A} \delta$ and $\mathrm{C}$ thermoreceptors. ${ }^{9}$ Thermal sensations and the perception of pain due to activation of $A \delta$ or $C$ high threshold mechanoreceptors or thermoreceptors, are primarily mediated to the brain via spinothalamocortical pathways. ${ }^{9}$ Dorsal column-medial lemniscal pathways, on the other hand, mediate the sensations of touch, pressure, lateral skin stretch, vibration, joint position, and two point discrimination. ${ }^{9}$ Two point discrimination has been used as a clinical measure of the cortical representation of the skin, and reduced two point discrimination thresholds have been related to increased cortical representation. ${ }^{10}$

The finding that thermal sensation was most reduced in painful skin areas whereas tactile thresholds were most increased in nonpainful denervated skin areas may indicate that the relative thalamic input from spinothalamic and dorsal column-medial lemniscal pathways is changed in patients with central pain. However, the difference in impairment of sensory perception in painful and nonpainful skin areas was non-significant indicating that central pain is not only dependent on the lesioning of spinothalamic or dorsal column-medial lemniscal pathways.

The main finding in this study is that the occurrence of abnormal evoked pain is significantly more common in painful than in nonpainful denervated skin areas. Several lines of evidence show that these changes in pain perception may be related to increased responsiveness (hyperexcitability) of nociceptive spinothalamic tract neurons. Mechanical allodynia was found in 12 of 15 patients in painful denervated skin areas, but in only one patient in the non-painful denervated skin area. Lateral skin stretch caused pain in 10 of 16 patients in painful denervated skin areas, but in no patients in the non-painful denervated skin areas. The frequency of wind up-like pain in painful skin areas was significantly higher than in non-painful denervated skin areas.

Mechanical allodynia (pain caused by non-noxious stimulation) in patients with nerve injury pain may result from activation of $\mathrm{A} \beta$ low threshold mechanoreceptors. ${ }^{11-13}$ A 
tentative explanation of mechanical allodynia is that hyperexcitable dorsal horn neurons normally responding to noxious stimulation (A $\delta$ and $\mathrm{C}$ high threshold nociceptors), start responding to activity in $\mathrm{A} \beta$ low threshold mechanoreceptors. ${ }^{1314}$ Accordingly, in painful denervated skin areas, activation of $A \beta$ low threshold mechanoreceptors might activate hyperexcitable spinothalamic tract neurons.

In electrophysiological studies it has been shown that repeated stimulation of $\mathrm{C}$ fibres causes hyperactivity and prolonged discharge (wind up) in the dorsal horn nociceptive cells. ${ }^{1516}$ In normal people repeated $\mathrm{A} \delta$ and $\mathrm{C}$ nociceptor stimulation cause temporal summation with increasing second pain and pain that outlasts the stimulation. ${ }^{13}$ Repeated stimulation of $\mathrm{A} \beta$ low threshold mechanoreceptors never produces pain in normal subjects, but produces abnormal wind up-like pain in patients with nerve injury pain. ${ }^{12}$ We demonstrated wind up-like pain in nine patients by repeated stimulation with a high intensity von Frey hair, normally activating $\mathrm{A} \delta$ and $\mathrm{C}$ nociceptors, and in two patients by stimulation with a low intensity von Frey hair, normally activating $\mathrm{A} \beta$ low threshold mechanoreceptors. It should be noted that $\mathrm{A} \beta$ and $\mathrm{A} \delta / \mathrm{C}$ mediated evoked pain have the same burning quality and nearly the same severity and tendency to radiate.

Several experimental studies have provided evidence that central deafferentation may produce hyperexcitability and spontaneous activity in central neurons, that may result in central pain with spontaneous continuous and intermittent pain and abnormal stimulus evoked pain. High frequency spontaneous activity was recorded in dorsal horn nociceptive cells at the level of the injury in a paraplegic patient with central pain. ${ }^{17}$ In patients with spinal cord injury and central pain, recordings in the ventroposterior thalamus disclosed increased receptive fields and increased spontaneous activity in the denervated cells. ${ }^{18}$ Electrical stimulation in the denervated region of the thalamus induced pain similar to the central pain. ${ }^{18}$ Epileptiform discharge recorded in hyperactive neurons in the thalamus were also demonstrated in patients with central pain due to causes other than spinal cord injury. ${ }^{19}$ In animals with a behavioural syndrome indicative of nerve injury pain due to dorsal rhizotomy, neuronal hyperactivity was recorded at the levels of the spinal cord dorsal horn, and at thalamic and cortical levels. ${ }^{20}$ Neuronal hyperactivity and hyperresponsiveness were also recorded at the thalamic and cortical levels in animals after chronic constriction injury to the sciatic nerve. ${ }^{21}$ The experimental data show that peripheral and central lesions cause similar changes in the activity of central neurons. This is of interest because central pain after spinal cord injury may also involve damage to spinal roots.
In conclusion, the present data provide clinical evidence that the development of central pain after spinal cord injury is not only dependent on the lesioning of spinothalamic or dorsal column-medial lemniscal pathways, but may involve the development of abnormal activity including hyperexcitability in nociceptive spinothalamic tract neurons.

This study was supported by grants from the Spinal Unit, Sunnaas Rehabilitation Hospital, and by the Anders Jahre fond for vitenskapens fremme.

1 Mariano AJ. Chronic pain and spinal cord injury. Clin $\mathcal{f}$ Pain 1992;8:87-92.

2 Davidoff $G$, Roth EJ. Clinical characteristics of central (dysesthetic) pain in spinal cord injury patients. In: Casey $\mathrm{KL}$, ed. Pain and central nervous system disease: the central pain syndromes. New York: Raven Press, 1991:77-83.

3 pain syndromes. New York: Raven Press, 1991:77-83. Textbook of pain. Edinburgh: Churchill Livingstone, 1994:871-902.

4 Tasker RR, DeCarvalho GTC, Dolan EJ. Intractable pain of spinal cord origin: clinical features and implications for surgery. $\mathcal{F}$ Neurosurg 1992;77:373-8.

5 Pagni CA. Central pain due to spinal cord and brain stem damage. In: Wall PD, Melzack R, eds. Textbook of pain. Edinburgh: Churchill Livingstone, 1989:634-55.

6 Beric A, Dimitrijevic MR, Lindblom U. Central dysesthesia syndrome in spinal cord injury patients. Pain 1988;34:109-16.

7 Fruhstorfer H, Lindblom U, Schmidt WG. Method for quantitative estimation of thermal thresholds in patients. $\mathcal{F}$ Neurol Neurosurg Psychiatry 1976;39:1071-5.

8 Eide PK, Jørum E, Stubhaug A, Bremnes J, Breivik H. Relief of post-herpetic neuralgia with the N-methyl-Daspartic acid receptor antagonist ketamine: a doubleblind, cross-over comparison with morphine and blind, cross-over compariso

9 Willis WD, Coggeshall RE. Sensory mechanisms of the spinal cord. New York: Plenum Press, 1991.

10 Song ZK, Cohen MJ, Ament PA, et al. Two-point discrimination thresholds in spinal cord injured patients with dysesthetic pain. Paraplegia 1993;31:485-93.

11 Cambell JN, Raja SN, Meyer RA, Mackinnon SE. Myelinated afferents signal the hyperalgesia associated with nerve injury. Pain 1988;32:89-94.

12 Price DD, Bennett GJ, Rafii A. Psychophysical observations on patients with neuropathic pain relieved by a sympathetic block. Pain 1989;36:273-88.

13 Price DD. Characterizing central mechanisms of pathological pain states by sensory testing and neurophysiological analysis. In: Casey KL, ed. Pain and central nervous system disease: the central pain syndromes. New York: Raven disease: the central pait

14 Bennett GJ. Neuropathic pain. In: Wall PD, Melzack RM, eds. Textbook of pain. Edinburgh: Churchill Livingstone, 1994:201-24

15 Davies SN, Lodge D. Evidence for involvement of $\mathrm{N}$ methylaspartate receptors in "wind-up" of class 2 neurones in the dorsal horn of the rat. Brain Res 1987; 424:402-6.

16 Dickenson AH, Sullivan AF. Evidence for a role of the NMDA receptor in the frequency dependent potentiation of deep rat dorsal horn nociceptive neurones following C fibre stimulation. Neuropharmacology 1987;26: 1235-8.

17 Loeser JD, Ward AA, White LE. Chronic deafferentation of human spinal cord neurons. $\mathcal{f}$ Neurosurg 1968;29: 48-50.

18 Lenz FA, Tasker RR, Dostrovsky JO et al. Abnormal single-unit activity and response to stimulation in the presumed ventrocaudal nucleus of patients with central pain. In: Dubner R, Gebhart GF, Bond MR, eds. Proceedings of the Vth world congress on pain. Amsterdam: Elsevier 1988:157-64.

19 Yamashiro K, Iwayama K, Kurihara $M$, et al. Neurones with epiletiform discharge in the central nervous system. Acta Neurochir 1991;(suppl 52):130-2.

20 Albe-Fessard D, Rampin O. Neurophysiological studies in rats deafferented by dorsal root sections. In: Nashold BS, Ovelmen-Levitt J, eds. Deafferentation pain syndromes. pathophysiology and treatment. New York: Raven Press, 1991:125-39.

21 Guilbaud G, Benoist JM, Jazat F, Gautron M. Neuronal responsiveness in the ventrobasal thalamic complex of rats with an experimental peripheral mononeuropathy. $\mathcal{f}$ Neurophysiol 1990;64:1537-54

22 Ditunno Jr JF, Young W, Donovan WH, Creasey G. The international standards booklet for neurological and functional classification of spinal cord injury. Paraplegia 1994;32:70-80. 